Hamburg Contemporary Economic Discussions

University of Hamburg

Faculty Economics and Social Science

Chair for Economic Policy

Von-Melle-Park 5

D-20146 Hamburg | Germany

Tel $+494042838-4622$

$\mathrm{Fax}+494042838-6251$

http://www.uni-hamburg.de/economicpolicy/

Editor: Wolfgang Maennig

Gabriel M. Ahlfeldt

University of Hamburg

Faculty Economics and Social Science

Chair for Economic Policy

Von-Melle-Park 5

D-20146 Hamburg | Germany

Tel $+494042838-5569$

Fax $+494042838-6251$

ahlfeldt@econ.uni-hamburg.de

Bastian Franke

University of Hamburg

Faculty Economics and Social Science

Von-Melle-Park 5

D-20146 Hamburg | Germany

Wolfgang Maennig

University of Hamburg

Faculty Economics and Social Science

Chair for Economic Policy

Von-Melle-Park 5

D-20146 Hamburg | Germany

Tel $+494042838-4622$

$\mathrm{Fax}+494042838-6251$

maennig@econ.uni-hamburg.de

ISSN 1865 - 2441 (Print)

ISSN 1865 - 7133 (Online)

ISBN 978 - 3 - 940369 - 62 - 8 (Print)

ISBN $978-3-940369-63-5$ (Online) 


\title{
Terrorism and the Regional and Religious Risk Perception of Foreigners: The Case of German Tourists
}

\begin{abstract}
This paper analyses how German tourists react to unanticipated shocks that alter their risk perception of selected tourism destinations. Using a difference-in-difference strategy which flexibly accounts for macroeconomic conditions and also addresses potential problems of serial correlation, we isolate significant effects of the 9/11 (2001) terrorist attacks, as well as for the attacks in Egypt (1997), Tunisia (2002), Morocco (2003) and Indonesia (2003). These terror attacks impacted especially on Islamic countries all over the world, indicating a transmission mechanism driven by ethnic and religious proximity. At the same time, tourism into Islamic countries was temporarily substituted by tourism to (south) European countries.
\end{abstract}

Keywords: Terrorism, 9/11, Islamic Countries, Tourism Demand

JEL classification: R19, D89

Version: March 2009

\section{Introduction}

Tourism is among the world's biggest industry (EILAT \& EINAV, 2004). International tourist arrivals more than doubled from 436 million in 1990 to 903 million in 2007. Receipts from international tourism in the same period increased from US\$264 billion to US\$856 billion. The annual growth rates of the number of international tourists have been positive since 1975, with the exception of 1980 , 2001 and 2003, and averaged about 4.6 per cent between 1975 and 2000, which roughly corresponds to 1.3 times the growth in global gross domestic product (WORLD TOURISM ORGANIZATION, 2007, 2008, n.d.). At the same time the tourism industry is susceptible to shocks, such as terror attacks or the incidence of infectious disease (EDMONDS \& MAK, 2006), which shape the risk perception of the destination countries. Against the background of the attacks on 11 Septem- 
ber (9/11), which opened up a new dimension ${ }^{1}$ in terrorism, as well as a series of other terror attacks between 2001 and 2003, studies of the effects on the tourism industry are, indeed, warranted. ${ }^{2}$

Even before the $9 / 11$ attacks there had been studies on the effects of exogenous shocks on touristic demand. For example, BRADY \& WIDDOWS (1988) extrapolated the number of flight passengers from the US to Europe in the summer of 1986 on the basis of a time series from 1973 to 1985 . By comparing actual numbers, they deduced a sharp tumble of up to 70 per cent (for Greece) due to terror attacks and the reactor meltdown in Chernobyl. To estimate the effects of terrorism on tourism, intervention models have been used predominantly since the 1990s, which are based on Auto-Regressive-Moving-Average (ARMA) methods. Alternatively, for example, classical regression models (WITT \& WITT, 1995), exponential smoothing (SAUNDERS, SHARP, \& WITT, 1987) or meta-analyses (CROUCH, 1992) are used. These studies have demonstrated significant effects of terrorism on tourism, which usually occur with a bit of a time delay within three to nine months following an attack and which vary in length of time (PIZAM \& FLEISCHER, 2002). This is contrasted by the conclusion drawn by COSHALL (2003), who found that the effect on the number of flight passengers from the US to Europe is immediate, following an attack, and lasts only three to four months. ENDERS, SANDLER, \& PARISE (1992) have also identified substitution effects in the travel behaviour of tourists, due to a change in risk classification. Typically they

1 Almost 3,000 people died, with damage running to about US\$80 billion, thus exceeding by far the previous terror attacks, which had claimed a maximum of 500 lives and damage in the amount of US\$2.9 billion (WALTER ENDERS \& SANDLER, 2006).

2 List of attacks with more than 40 dead attributable to Islamist terrorists since 11 Sep 2001: 12 Oct 2005, Indonesia-Bali, 202 dead (bomb attacks on two nightclubs); 24 Oct 2002, RussiaMoscow, 129 dead (hostage-taking terminated in a musical theatre); 16 May 2003, MoroccoCasablanca, 45 dead (five simultaneous attacks on Western and Jewish facilities); 16 Nov and 20 Nov 2003, Turkey-Istanbul, 45 dead (bomb attacks on synagogues and in the inner city); 6 Feb 2004, Russia-Moscow, 40 dead (suicide assassin in an underground train); 2 March 2004, Iraq-Baghdad, Kerbela, 271 dead (attacks during Shiite Ashura commemoration); 11 March 2004, Spain-Madrid, 191 dead (attacks on 4 commuter trains); 24 Aug 2004, Russia, 90 dead (two plane crashes); 1 Sep 2004, North-Ossetia-Beslan, 330 dead, among them 196 children (fatal end of a hostage-taking in a school); 7 July 2005, Great Britain-London, at least 56 dead (bomb attacks on an underground train and a bus); 23 July 2005, Egypt-Sharm el-Sheikh, up to 88 dead (bomb attacks on a bazaar, the Ghazala Gardens Hotel and a café). Source: NONNENMACHER (2005). 
would substitute trips to geographically closer countries for intercontinental travel. Similar effects were isolated later on by VESTER (2001), who was also the first to demonstrate regional spillover effects. From the mid-1990s there have also been more studies into the effects in other geographic regions, besides those regarding the tourist demand in Europe and the US, with most of the studies dealing with the conflict between Israel and Palestinians (e.g. FLEISCHER \& BUCCOLA, 2002; MANSFELD, 1999; PIZAM \& FLEISCHER, 2002). PIZAM \& FLEISCHER (2002) found that certain countries recover relatively quickly from terror attacks if they are not followed by additional attacks. Repeated terror attacks, however, can result in a lasting decline in tourist demand or wipe it out entirely. The relevance of attack intensity for effects on demand has been confirmed by DRAKOS \& KUTAN (2003), who have used a Seemingly-Unrelated-Regression model. Apart from studies of an economic and econometric nature, there are also ones that examine terror attacks on the basis of literature research and interviews (PIZAM, 1999).

BONHAM, EDMONDS \& MAK (2006) and EDMONDS \& MAK (2006) demonstrate that, following the $9 / 11$ attacks, the total worldwide international tourist arrivals decreased in the same year, 2001, only by less than one per cent over 2000. In 2002 they had already moved up again above 2000 levels. At the same time, though, some countries, such as the US, experience some extreme effects on tourist demand, which are compensated in specific regions, such as Hawaii, by a substitution effect in the behaviour of American tourists, who opt for domestic, rather than foreign, travel. ${ }^{3}$ EDMONDS \& MAK (2006) arrive at heterogeneous post-9/11 effects also for the Asian-Pacific region. While certain countries can recover quickly-also due to simplified entry requirements (e.g., Singapore)others suffer a sustained decline in tourist numbers (e.g., Malaysia) as a result of follow-up attacks, the infectious disease SARS and the uncertain geopolitical situation. Similarly, countries like Morocco and Tunisia took longer to recover

For further analyses of tourist demand in the United States, cf. READY \& DOBIE (2003), LEE, OH, \& O'LEARY (2005) as well as RUPP, HOLMES, \& DESIMONE (2005). BONHAM, EDMONDS, \& MAK (2006) have found that, on the basis of growth trends before and after $9 / 11$, a recovery effect is not to be expected in the near future. 
from the 9/11 attack than other Islamic countries, because these two countries suffered additional attacks in 2002 and 2003, respectively. What is more, their tourism industries are geared to Western, especially European markets, which is why they were particularly hit by the substitution effect of European tourists choosing to stay away from Islamic destination countries, while there was no compensation from an increase in tourists from other Islamic countries (ALHAMARNEH, 2004). Anecdotic evidence indicates that Islamic countries are especially impacted by substitution effects that are caused by changes in risk perception (LEIBRITZ, 2004).

The number of studies examining the effects of terror attacks on tourist demand on the basis of panel data is relatively small. The paper by GARIN-MUNOZ \& AMARAL (2000) was published before the 9/11 attacks and examines the determinants of tourist demand in Spain, identifying a negative effect stemming from the Gulf War. Using indices of the PRS Group, ${ }^{4}$ which map internal, external and ethnic conflict potential as well as security risks, SEQUIRA \& NUNES (2008) and EILAT \& EINAV (2004) have determined that a higher security risk produces significantly lower numbers of tourists.

The present work supplements previous publications in a number of respects. First, it studies a range of exogenous shocks on tourism that are of distinct magnitude. Besides regional effects of $9 / 11$, it also looks at relatively minor terror attacks before and after the 9/11 attacks. It is also the first study which explicitly tests substitution and adaptation effects in the wake of terror attacks with regard to geographic as well as religious proximity while also taking into account substitution from long-distance to short-distance trips and distinguishing between long term and short term effects. In addition, it is the first multivariate work to study shock-based changes in the travel demand of a regionally limited group (German tourists, who are among the largest tourist groups in the world) and how those changes affect all the countries for which sufficient data were available-instead of examining for a selected number of target regions the changes brought on by

4 The Political Risk Services Group publishes data on political risk analyses. More information can be found at www.prsgroup.com. 
the travel behaviour of tourists originating in various possible source regions. This is highly interesting, because this approach allows for an explicit study of the substitution behaviour of consumers. It is also the first work which analyses the impact of terror attacks with the Difference-in-Difference-Approach (DD), which differentiates further tourism determinants and macro-economic ambient factors that affect general tourist demand. It has been shown that a decline in tourist numbers occurs not only as a consequence of terror attacks, particularly those of $9 / 11$, in the countries affected as well as neighbouring countries, but also has global effects in countries with a predominantly Islamic population. A heightened risk expectation is, thus, transferred not only through geographic but also ethnic and religious proximity. Throughout the paper, our analysis concentrates on isolating relative effects on tourist demand from which adjustments in risk perception can be inferred while absolute changes in tourist demand and the respective determinants are not within the narrow focus of this study. Section 2 elaborates on data and methods, section 3 presents results, and section 4 concludes.

\section{Data and Empirical Strategy}

The empirical study is based on annual data $a^{5}$ on arrivals of German tourists in selected target countries between 1993 and 2005, which have been obtained from the German Federal Statistical Office (STATISTISCHES BUNDESAMT DEUTSCHLAND 2007). ${ }^{6}$ In total, the data cover 192 countries. However, the data for one or several years are missing for some countries, which therefore had to be excluded from the panel study. By using growth rates, it was possible to account for the heterogeneity of the countries represented in the sample, while largely ruling out distortions due to different collection methods in determining the number of tourists.' However, some countries, e.g., Turkey or Zimbabwe, changed the

Monthly data for the countries taken into account are not available.

6 The German Federal Statistical Office obtains the data from the UN World Tourism Organization (UNWTO).

7 Apart from border arrivals of tourists, excluding day-trippers, some countries also collected data on border arrivals including day-trippers, arrivals at hotels and similar facilities or arrivals at all lodgings. 
method of calculating tourist numbers in the period under review, which is why they, too, have been excluded in order to avoid any distortion. Also excluded from the study are countries that were visited by fewer than 1,000 German tourists in at least one year due to high volatility in the tourism volume and limited informative value regarding overall trends. After filtering countries in this manner, a total of 82 countries remained for the purposes of the study.

In the context of the study, the differentiation between Islamic and non-Islamic countries in regard to the effects of terror attacks on tourism volume depends on whether a country is perceived as an Islamic country by (German) tourists or not. The percentage of the Muslim population (THE WORLD FACTBOOK OF THE CIA, 2008) is an obvious measure, while the definition of a threshold value is not that apparent from the start. In order to ensure the robustness of results, all estimates have been done using two treatment groups defined as the percentage of the Muslim population at 50 per cent and 85 per cent, respectively. While results are qualitatively comparable for both specifications throughout our analyses, we present results corresponding to the latter specification since the respective definition ensures a perception as an "Islamic country". ${ }^{8}$ Figure 1 shows the countries included in our analyses by proportion of Islamic population as well as the terrorist attacks considered in this analysis.

Fig. 1 Countries and Terrorist-Attacks

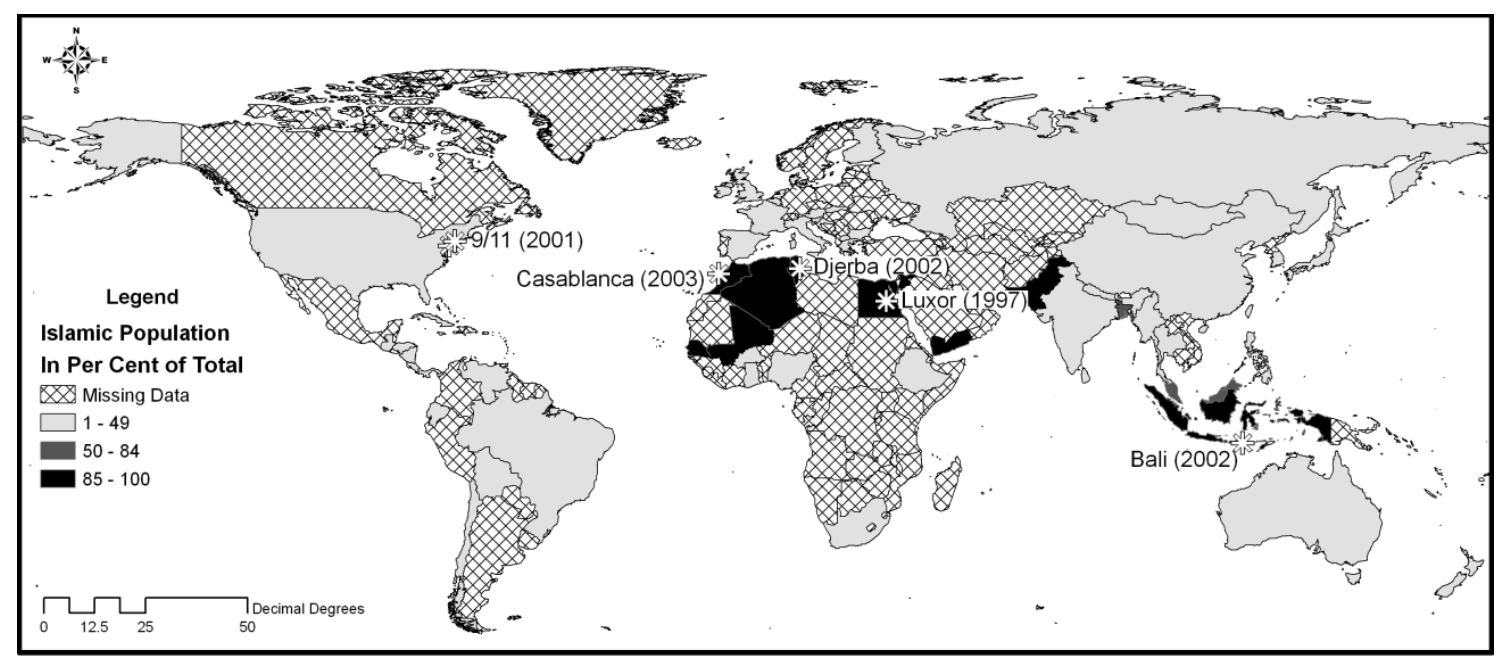

Notes: Own Illustration.

${ }^{8}$ As expected, effects found for the $50 \%$ treatment groups are generally slightly attenuated. 
We use the DD method, which essentially examines whether the development in certain countries (treatment group) before and after the event studied (treatment) is different from the control group, which represents a general macroeconomic development. Demand in tourism is relatively strongly determined by economic cycles, seasons and trends, as well as susceptible to macroeconomic shocks, such as a rise in oil prices, which increases the cost of flying.

The DD estimator employed here, $\hat{\beta}$, differentiates the average annual growth in the tourism volume $(\overline{\mathrm{Tou}})$ via groups of countries (treat/control) and through time (before/after); this way the relative change in the tourism volume following an exogenous event, the terror attack, is isolated from other factors.

$$
\hat{\beta}=\left(\overline{\text { Tou }}_{\text {after }}^{\text {control }}-\overline{\text { Tou }}_{\text {before }}^{\text {control }}\right)-\left(\overline{\text { Tou }}_{\text {after }}^{\text {treat }}-\overline{\text { Tou }}_{\text {before }}^{\text {treat }}\right)
$$

The treatment effect is estimated in the following empirical basic specification:

$$
\begin{gathered}
\text { Tou }_{i t}=\beta\left(\text { treat }_{i} \times \text { post }_{t}\right)+d_{t}+\mu_{i t}, \\
\text { where } \mu_{i t}=\varphi_{i}+\varepsilon_{i t}
\end{gathered}
$$

treat $_{i}$ is a dummy variable denoting the treatment group consisting either of islamic countries or countries of determined treatment regions. post $t_{t}$ denotes the period after the considered attack and $\beta$ is the treatment coefficient to be estimated. The coefficient states the average change in the growth rates, caused by an attack, of German tourist numbers in countries of the treatment group in relation to the other countries. Similar to AHLFELDT \& MAENNIG ([in press]) and REDDING \& STURM (2008), this approach controlles for macro-economic shocks and general trends by means of a full set of (yearly) time dummies $\left(d_{t}\right) .{ }^{9}$ Since unobserved effects can be taken into account for any point in time in this way, a parametric specification of the general market development is unnecessary. Longterm trends, short-term shocks and cyclical developments can be captured in a flexible manner. The estimator facilitates composite error terms $\mu_{i t}$ allowing for 
unobserved country effects $\varphi_{i}$, which control for heterogeneity in long-term growth trends while $\varepsilon_{i t}$ is an error term satisfying the usual conditions. ${ }^{10}$

In order to distinguish between short-term and long-term effects, we, similar to AHLFELDT \& MAENNIG ([in press]), extend specification (2) by an interactive term of the treatment identifier and a vector of yearly dummy variables denoting the first years after the considered terrorist attack $\left(S_{H O R T_{t}}\right)$.

$$
\text { Tou }_{i t}=\beta\left(\text { treat }_{i} \times \text { post }_{t}\right)+\left(\text { treat }_{i} \times \text { SHORT }_{t}\right) b+d_{t}+\mu_{i t},
$$

where $b$ is a set of coefficients giving the difference in the estimated treatment effect between the period immediately following the shock, and the long-term effect $\beta$. In a similar manner we employ an extended specification in order to account for a potential substitution effect from long-distance to short-distance journeys over the course of our study period, possibly owed to changes in preferences, e.g. due to climate change.

$$
\text { Tou }_{i t}=\beta\left(\text { treat }_{i} \times \text { post }_{t}\right)+\left(\text { treat }_{i} \times \text { SHORT }_{t}\right) b+\left(\text { dist }_{i} \times d_{t}\right) c+d_{t}+\mu_{i t}(4)
$$

where dist $t_{i}$ is the great circle distance between the geographic centroids of Germany and country $i$ and $c$ is a set of coefficients to be estimated that give the marginal changes in average growth rates for a $1,000 \mathrm{~km}$ increase in distance.

A common phenomenon in DD approaches is serial correlation in the error terms, which causes inefficiency of estimated intervention effects. Since the $L M$ test for serial correlation in a fixed effects model (BALTAGI, 2001) clearly rejects the hypothesis of no serial correlation, ${ }^{11}$ we use an arbitrary variance-covariance matrix as recommended by BERTRAND, DUFLO, \& MULLAINATHAN (2004).

${ }^{10}$ This specification is equivalent to the consideration of a full set of country dummies employed by DI TELLA \& SCHARGRODSKY (2004). Note that compared to standard DD approaches a noninteracted treat term is missing due to perfect collinearity with country effects.

${ }^{11}$ The $L M$ test statistic is $L M_{5}=\sqrt{N T^{2} /(T-1)\left(\tilde{v}^{\prime} \tilde{v}_{-1} / \tilde{v}^{\prime} \tilde{v}\right)}$; asymptotically distributed as $\mathrm{N}(0,1)$. 


\section{Results}

As a first step, the effects of the 9/11 attacks on the tourist demand of German tourists in African, American, Asian, Australian, European and Middle-East countries is examined on the basis of model specification (3). ${ }^{12}$ Since the 9/11 attacks occurred towards the end of 2001 and the literature points to a delay in the effects of between three and nine months after terror attacks (e.g. BERTRAND, DUFLO, \& MULLAINATHAN, 2004; ENDERS \& SANDLER, 1991; ENDERS, SANDLER, \& PARISE, 1992; TREMBLAY, 1989), this study, based on annual data, defines the period following the attacks as the period from 2002. Results remain qualitatively unchanged if the post-period starts in $2001 .^{13}$

Tab. 1 The Effects of 9/11 on Various (Treatment) Regions

\begin{tabular}{cccccccc}
\hline \hline & $\begin{array}{c}(1) \\
\text { Africa }\end{array}$ & $\begin{array}{c}(2) \\
\text { America }\end{array}$ & $\begin{array}{c}(3) \\
\text { Australia }\end{array}$ & $\begin{array}{c}(4) \\
\text { Asia }\end{array}$ & $\begin{array}{c}(5) \\
\text { Middle } \\
\text { East }\end{array}$ & $\begin{array}{c}(6) \\
\text { Europe }\end{array}$ & $\begin{array}{c}(7) \\
\text { Southern } \\
\text { Europe }\end{array}$ \\
\hline post $\times$ treat & -.056 & .009 & -.029 & $.120^{* *}$ & $.218^{*}$ & $-.089^{*}$ & $-.196^{* *}$ \\
& $(.047)$ & $(.041)$ & $(.032)$ & $(.044)$ & $(.110)$ & $(.044)$ & $(.067)$ \\
post_1_2 $\times$ treat & .057 & .045 & .036 & $-.172^{\cdots *}$ & $-.370^{\cdots *}$ & $.088^{*}$ & $.144^{*}$ \\
& $(.073)$ & $(.055)$ & $(.027)$ & $(.059)$ & $(.108)$ & $(.048)$ & $(.061)$ \\
\hline Sample & World & World & World & World & World & World & World \\
\hline Observations & 984 & 984 & 984 & 984 & 984 & 984 & 984 \\
R $^{2}$ & .156 & .156 & .155 & .165 & .165 & .159 & .163 \\
\hline
\end{tabular}

Notes: post represents the period from the year following the attack to the end of 2005. post_1_2 represents the two years following the attack. Robust standard errors (in parentheses) are adjusted for clustering on country. ${ }^{*},{ }^{* *},{ }^{* * *}$ : significant at the $10 / 5 / 1 \%$ level.

For African and American countries as well as Australia (columns 1 to 3), no statistically significant deviations have been identified from general tourism trends following 9/11. The results for countries in the Middle East (column 4), however, point to a considerable and significant decline during the two years after the 9/11 attacks, followed by recovery. Accordingly, the annual growth rates of the German tourist volume in the Middle East in 2002 and 2003 amounted, on average,

12 The delimitation of treatment groups is based on the official classification of the German Federal Statistical Office (STATISTISCHES BUNDESAMT DEUTSCHLAND 2007).

${ }^{13}$ Short-run effects are slightly reduced due to the positive trends in 2001 prior to 9/11. 
to about $|21.8-37.0|=15.2$ percentage points in each year below those for the reference group, which consists of all the countries not included in the treatment group. Recovery set in after 2003, with annual growth rates that averaged 21.8 percentage points above the average for the rest of the world. Similar, yet attenuated, effects occurred in the region of Asia. European countries exhibit an opposite pattern (column 5). In 2004 and 2005 the growth rates were about 8.9 percentage points below the global growth rates, while in 2002 and 2003 the median growth rates corresponded approximately to the average of the rest of the world.

It seems that it is mostly countries in Asia, particularly in the Middle East, that suffered the negative effects of 9/11 on their tourist volumes. From 2004, however, we see significantly positive recovery effects, which go hand in hand with a considerable relative decline in the tourist volume in European, primarily Southern European, countries. These findings confirm the substitution effect in travel behaviour discussed by, for example, LEIBRITZ (2004) or VESTER (2001), and demonstrated by BONHAM, EDMONDS, \& MAK (2006), EDMONDS \& MAK (2006) as well as ENDERS, SANDLER, \& PARISE (1992).

Since the time after $9 / 11$ the US saw a significant reduction in tourist volume, especially in the Middle East, one must inquire about the underlying transmission mechanism. Obviously the risk perception of the tourist destination did not just change because of geographic proximity. Instead, the results point to a special decline in Islamic countries, which make up a disproportionate percentage of the Middle East. This special decline has been discussed in the literature, but has not been proved statistically (AL-HAMARNEH, 2004; LEIBRITZ, 2004). In order to examine more closely a potential transmission process behind the risk perception of German tourists, which is driven not geographically but by ethnic-religious factors, in the second step of the study the effects on the tourist flows, particularly into Islamic countries, are examined.

Column 1 of Table 2 summarises the effects of $9 / 11$ on a treatment group that consists of Islamic countries and is based on the DD specification (2). It is interesting to note that there was no systematic deviation in Islamic countries from the 
trends in non-Islamic countries from 2002 to 2005 across the entire post period. But if a distinction is made between short- and long-term effects, it becomes clear that the growth rates in Islamic countries in 2002 and 2003 were approx. 10 percentage points below those of non-Islamic countries, while they exceeded the latter by an almost identical value after 2003 (column 2). If a further differentiation is made, between the individual years immediately after the attack, a somewhat more marked effect for 2003, compared to 2002, emerges (column 3).

Since we cannot reject that there is an ongoing substitution effect from longdistance to short-distance journeys owing to other determinants than perceived risk of tourism destinations, we repeat the estimates using specification (4). If the average Islamic countries were located at a larger distance from Germany compared to the countries of the control group, then the respective substitution effect could have been erroneously attributed to the characteristic "Islamic". Indeed, over the course of our study period such a tendency for substituting shortdistance for long-distance journeys is observable. For a number of years there is a significantly negative relationship between growth rates in tourist demand and distance to the respective destination, indicating a relative increase in demand for closer locations at the expense of farther destinations. This relationship is particularly significant for the year after $9 / 11$, confirming the results by ENDERS, SANDLER, \& PARISE (1992). ${ }^{14}$ Nevertheless, magnitude and precision of the key coefficients of interest remain almost unaffected by introduction of the geographic control variables, thereby discarding this substitution effect as a potential source of bias.

${ }^{14}$ Correlation coefficients between growth in tourism and distance to destination are negative for all years, however, only significant at conventional levels for 1996 (weakly) and 2002. 
Tab. 2 Effects of 9/11 Attacks on Islamic Countries

\begin{tabular}{|c|c|c|c|c|}
\hline & \multicolumn{4}{|c|}{ Islamic Countries } \\
\hline & (1) & $(2)$ & (3) & (4) \\
\hline post $\times$ treat & $\begin{array}{l}.003 \\
(.041)\end{array}$ & $\begin{array}{l}.095^{*} \\
(.050)\end{array}$ & $\begin{array}{l}.095^{*} \\
(.050)\end{array}$ & $\begin{array}{l}.104^{*} \\
(.523)\end{array}$ \\
\hline post_1_2 $\times$ treat & & $\begin{array}{l}-.197^{* * *} \\
(.068)\end{array}$ & & \\
\hline post_ $1 \times$ treat & & & $\begin{array}{l}-.169^{*} \\
(.086)\end{array}$ & $\begin{array}{l}-.191 " \\
(.893)\end{array}$ \\
\hline post_ $2 \times$ treat & & & $\begin{array}{l}-.224 \\
(.066)\end{array}$ & $\begin{array}{l}-.220^{* *} \\
(.067)\end{array}$ \\
\hline dist $\times 1994$ & & & & $\begin{array}{l}-.004 \\
(.006)\end{array}$ \\
\hline dist $\times 1995$ & & & & $\begin{array}{l}-.008 \\
(.005)\end{array}$ \\
\hline dist $\times 1996$ & & & & $\begin{array}{c}-.026 " \\
(.010)\end{array}$ \\
\hline dist $\times 1997$ & & & & $\begin{array}{l}-.013^{* *} \\
(.004)\end{array}$ \\
\hline dist $\times 1998$ & & & & $\begin{array}{l}-.010^{*} \\
(.004)\end{array}$ \\
\hline dist $\times 1999$ & & & & $\begin{array}{c}-.013^{*} \\
(.008)\end{array}$ \\
\hline dist $\times 2000$ & & & & $\begin{array}{l}-.011^{*} \\
(.006)\end{array}$ \\
\hline dist $\times 2001$ & & & & $\begin{array}{l}-.009^{*} \\
(.005)\end{array}$ \\
\hline dist $\times 2002$ & & & & $\begin{array}{l}-.021 \\
(.004)\end{array}$ \\
\hline dist $\times 2003$ & & & & $\begin{array}{l}-.003 \\
(.004)\end{array}$ \\
\hline dist $\times 2004$ & & & & $\begin{array}{l}-.004 \\
(.004)\end{array}$ \\
\hline dist $\times 2005$ & & & & $\begin{array}{l}-.007 \\
(.005)\end{array}$ \\
\hline Sample & World & World & World & World \\
\hline Observations & 984 & 984 & 984 & 984 \\
\hline $\mathrm{R}^{2}$ & .155 & .162 & .162 & .174 \\
\hline
\end{tabular}

Notes: post represents the period from the year following the attack to the end of 2005 . post_1_2 represents the two years following the attack, post_1 the year immediately after the attack and post 2 the second year after the attack. Robust standard errors (in parentheses) are adjusted for clustering on country. ${ }^{*},{ }^{* *},{ }^{* * *}$ : significant at the $10 / 5 / 1 \%$ level.

To check the robustness of the substitution effect in the travel behaviour of German tourists, identified in the global sample, away from Islamic to non-Islamic countries, the results of regionally limited country groups are compared, which 
show similarities in factors important to tourists, such as climate, vegetation and the range of tourist opportunities. The study of the effects of the $9 / 11$ attacks on the growth rates of tourist arrivals in Islamic countries is done in a manner analogous to Table 1 for Africa, Mediterranean countries and Asian countries. No countries in South or North America as well as Australia have been assigned to the Islamic treatment group. The Mediterranean region consists of countries in North Africa, Southern Europe and the Middle East.

Tab. 3 The Effects of 9/11 in Islamic Countries in Different Regions

\begin{tabular}{|c|c|c|c|c|c|c|}
\hline & \multicolumn{2}{|c|}{ Africa } & \multicolumn{2}{|c|}{ Mediterranean } & \multicolumn{2}{|c|}{ Asia } \\
\hline & $(1)$ & $(2)$ & (3) & $(4)$ & (5) & (6) \\
\hline post $\times$ treat & $\begin{array}{c}.159^{* *} \\
(.072)\end{array}$ & $\begin{array}{c}.159^{* *} \\
(.072)\end{array}$ & $\begin{array}{l}.168 \\
(.102)\end{array}$ & $\begin{array}{c}.168 \\
(.102)\end{array}$ & $\begin{array}{c}.061 \\
(.096)\end{array}$ & $\begin{array}{c}.061 \\
(.096)\end{array}$ \\
\hline post_1_2 $\times$ treat & $\begin{array}{l}-.379^{* * *} \\
(.080)\end{array}$ & & $\begin{array}{l}-.298 " \\
(.114)\end{array}$ & & $\begin{array}{l}-.081 \\
(.147)\end{array}$ & \\
\hline post_ $1 \times$ treat & & $\begin{array}{l}-.364^{* *} \\
(.133)\end{array}$ & & $\begin{array}{l}-.309 \\
(.183)\end{array}$ & & $\begin{array}{l}-.102 \\
(.167)\end{array}$ \\
\hline post_ $2 \times$ treat & & $\begin{array}{c}-.394^{* *} \\
(.056)\end{array}$ & & $\begin{array}{l}-.288^{* * *} \\
(.059)\end{array}$ & & $\begin{array}{l}-.060 \\
(.144)\end{array}$ \\
\hline Sample & \multicolumn{2}{|c|}{ Africa } & \multicolumn{2}{|c|}{ Mediterranean } & \multicolumn{2}{|c|}{ Asia } \\
\hline Obs & 156 & 156 & 180 & 180 & 276 & 276 \\
\hline$R^{2}$ & .176 & .176 & .207 & .207 & .278 & .278 \\
\hline \multicolumn{7}{|c|}{$\begin{array}{l}\text { post represents the period from the year following the attack to the end of } 2005 \text {. } \\
\text { post_1_2 represents the two years following the attack, post_ } 1 \text { the year immediately } \\
\text { after the attack and post_2 the second year after the attack. Robust standard errors (in } \\
\text { parentheses) are adjusted for clustering on country. }{ }^{*},{ }^{* *},{ }^{* * *} \text { : significant at the } 10 / 5 / 1 \% \\
\text { level. }\end{array}$} \\
\hline
\end{tabular}

The findings for African countries and Mediterranean countries (Table 3, columns 1-4) confirm a significant, short-term decline in tourism in Islamic countries following the 9/11 attacks, which are characterised, as far as African Islamic countries are concerned, by an (overcompensating) recovery starting in 2004. The effects are greater in quantity both for Africa and the Mediterranean region than for the global study (Table 2), which, again, implies specific ethnic-religious effects of terrorism on tourism. The results for Asia show the same quality of pattern as those obtained from the global sample, but they are not statistically significant. 
In order to compare the effects of the 9/11 terror attacks, which are geographically remote from Islamic countries, with the effects of-also Islamically motivated-terror attacks, additional terror attacks have been analysed in a further step (CRP-INFOTEC, 2008a, 2008b):

- On 17 November 199770 people, among them 50 foreign tourists, were killed in Luxor (Egypt) in an attack by the group Gamaa al Islamiya.

- On 11 April 2002 the group Al-Oaida killed 21 people, among them 14 German tourists, in Djerba (Tunisia).

- On 12 October 2002202 people, among them 123 foreign tourists, perished on the island of Bali (Indonesia) in an attack by the group Jemaah Islamiya.

- On 16 May 2003 an attack by the group Salafiya in Casablanca (Morocco) resulted in 43 deaths.

The criteria for selecting attacks include the location of the attack (an Islamic country where data on arrivals of German tourists are available) and, above all, the significance of the attack for tourism. Therefore, attacks have been selected that focused on tourist targets and whose victims were primarily tourists. The attack in Egypt in 1997 is an event that occurred before the 9/11 attacks. It was selected so as to have a framework for comparison with the effects of the 9/11 terror attacks. The Indonesia case allows for insight into the effects on predominantly non-Islamic neighbouring states. This should allow for conclusions about geographic proximity as a determinant in the transmission process of risk perception.

Similar to the 9/11 attacks, for the purposes of analysing the terror attacks in Table 4, the study looked at the periods after the attacks, with special emphasis on the short-term effects in the first two years. In the case of Egypt, the year 1998 has been marked as the start of the post period, because the attack occurred towards the end of 1997 (11 November). Column 1, analogous to column 3 in Table 2 , has been controlled for tourism development in Islamic countries (isl) by isolat- 
ing the years 1998-2000. Columns 2 to 6 are similarly controlled for the effects of $9 / 11$ on Islamic countries. This way the treatment coefficients can be used to test for deviations in tourism development in the treatment countries in relation to the trends encountered in Islamic countries. ${ }^{15}$

Egypt experienced a considerable decline in tourist volume following the 1998 attack, but saw an almost complete recovery after one year. In the three years 1998, 1999 and 2000 it actually recorded significantly higher growth.

The attack in Tunisia occurred on 11 April 2002, which allowed for the effects on tourist numbers to be tested in the same year. In contrast to column 1, the findings in 2 point to a weaker development (yet only slightly significant) of Tunisia's tourist volume. Over the long term the growth rates were 9.2 percentage points below the reference group; in the short term the year of the attack saw an additional significant effect of minus 19.6 percentage points. While the short-term effect was less pronounced than in the 1998 attack in Egypt, Tunisia did not see its tourist numbers recover over the medium term. Tunisia has not profited from the generally positive development in Islamic countries after 2003, which became apparent in Table 2 and was confirmed in columns 2-5 of Table 4.

The attacks in Morocco occurred on 16 May 2003. As a result, the study looked at the effects from 2003 onwards. A (slightly significant) negative relative long-term effect has been identified on growth rates of a size similar to Tunisia. The shortterm effects are not statistically significant. This could be explained by the fact that the attack in Morocco, unlike the attacks in Egypt and Tunisia, did not affect German tourists directly, which is why coverage in the German media was less comprehensive. In addition, there is the possibility of an "adaptation effect", which causes tourists to react less sensitively to attacks. Looking at the 2002 attack in Tunisia, the short-term decline in tourist numbers was already less than for the 1997 attack in Egypt.

${ }^{15}$ Results remain qualitatively unchanged if controls for impact on Islamic countries are omitted. 
The two attacks on Bali in Indonesia on 12 October 2002 were the most consequential terror attacks by an Islamic group after $9 / 11$ and resulted in over 200 deaths. Unlike the attacks in Tunisia and Morocco, Indonesia, however, exhibited only a short-term, statistically significant, effect of approx. 13 percentage points (column 4) in 2003 compared to the reference group of Islamic countries. It should be noted in this context that the Southeastern region of Asia was affected that same year by the infectious disease SARS (Severe Acute Respiratory Syndrome), which also shaped the risk perception of the region. Indonesia itself saw relatively little fallout from SARS. Therefore, the treatment group in column 5 is expanded to include the Southeast-Asian countries Malaysia, Myanmar, the Philippines, Singapore and Thailand in order to test the joint impact of the terror attack and SARS in the region of Southeast Asia (SEA). The region exhibits only a barely significantly but somewhat stronger decline in tourism in 2003 than in Indonesia, which cannot be explained by regional spillover effects of the attack in Indonesia. To test for any significant deviation in the development in Indonesia compared to the region, the specification in column 4 is expanded in column 6 to include interactive terms that capture the development in the entire region. While there was significant difference between the development of Indonesia and its neighbouring states in the long term as well as in the first year, 2004 saw the trend go into reverse. Thus the region without Indonesia shows a slightly significant recovery, while the tourist volume in Indonesia drops once again in relative terms, with this negative effect actually exceeding the positive regional effect. It follows therefore that the joint impact of the terror attack and SARS had longer-lasting effects in Indonesia than in its neighbouring states. Assuming that the effects of the terror attack on Bali diminish with distance, a conclusion can be drawn that the terror attack, compared to SARS, has produced a longer-term adjustment of tourists' risk perception. 
Tab. 4 Terror Effects in Countries that Suffered Attacks

\begin{tabular}{|c|c|c|c|c|c|c|}
\hline & $\begin{array}{c}(1) \\
\text { Egypt }\end{array}$ & $\begin{array}{c}(2) \\
\text { Tunisia }\end{array}$ & $\begin{array}{c}(3) \\
\text { Morocco }\end{array}$ & $\begin{array}{c}\text { (4) } \\
\text { Indonesia }\end{array}$ & $\begin{array}{l}(5) \\
\text { SEA }\end{array}$ & $\begin{array}{c}(6) \\
\text { Indonesia }\end{array}$ \\
\hline post $\times$ treat & $\begin{array}{l}.463^{* * *} \\
(.097)\end{array}$ & $\begin{array}{l}-.092^{*} \\
(.049)\end{array}$ & $\begin{array}{c}-.087^{*} \\
(.051)\end{array}$ & $\begin{array}{c}.027 \\
(.051)\end{array}$ & $\begin{array}{c}-.003 \\
(.053)\end{array}$ & $\begin{array}{c}.027 \\
(.078)\end{array}$ \\
\hline post_1 $1 \times$ treat & $\begin{array}{l}-.932 \\
(.960)\end{array}$ & $\begin{array}{l}-.196^{* *} \\
(.085)\end{array}$ & $\begin{array}{l}-.036 \\
(.066)\end{array}$ & $\begin{array}{l}-.133 " \\
(.065)\end{array}$ & $\begin{array}{c}-.146^{*} \\
(.070)\end{array}$ & $\begin{array}{c}.018 \\
(.104)\end{array}$ \\
\hline post_2 $2 \times$ treat & $\begin{array}{l}.382^{* * *} \\
(.082)\end{array}$ & $\begin{array}{c}-.025 \\
(.064)\end{array}$ & $\begin{array}{c}.020 \\
(.025)\end{array}$ & $\begin{array}{r}-.031 \\
(.025)\end{array}$ & $\begin{array}{c}.061 \\
(.041)\end{array}$ & $\begin{array}{l}-.105^{* * *} \\
(.032)\end{array}$ \\
\hline post $\times$ SEA & & & & & & $\begin{array}{c}.018 \\
(.104)\end{array}$ \\
\hline post_1 $1 \times$ SEA & & & & & & $\begin{array}{c}-.149^{*} \\
(.083)\end{array}$ \\
\hline post_2 $\times$ SEA & & & & & & $\begin{array}{c}.078^{*} \\
(.041)\end{array}$ \\
\hline post $\times$ isl & $\begin{array}{c}-.126 \\
(.101)\end{array}$ & & & & & \\
\hline post_1 $\times$ isl & $\begin{array}{c}.169 \\
(.103)\end{array}$ & & & & & \\
\hline post_2 2 isl & $\begin{array}{c}.224 " \\
(.094)\end{array}$ & & & & & \\
\hline $2002-2005 \times$ isl & & $\begin{array}{c}.103^{*} \\
(.054)\end{array}$ & $\begin{array}{c}.102^{*} \\
(.054)\end{array}$ & $\begin{array}{c}.094^{*} \\
(.541)\end{array}$ & $\begin{array}{c}.095^{*} \\
(.050)\end{array}$ & $\begin{array}{c}.096^{*} \\
(.055)\end{array}$ \\
\hline $2002 \times$ isl & & $\begin{array}{l}-.152 \\
(.054)\end{array}$ & $\begin{array}{c}-.176 " \\
(.088)\end{array}$ & $\begin{array}{l}-.168^{*} \\
(.089)\end{array}$ & $\begin{array}{c}-.169^{* *} \\
(.086)\end{array}$ & $\begin{array}{l}-.171^{*} \\
(.089)\end{array}$ \\
\hline $2003 \times$ isl & & $\begin{array}{l}-.222^{* * *} \\
(.071)\end{array}$ & $\begin{array}{l}-.220^{* * *} \\
(.071)\end{array}$ & $\begin{array}{l}-.213^{* *} \\
(.070)\end{array}$ & $\begin{array}{l}-.221^{* * *} \\
(.065)\end{array}$ & $\begin{array}{l}-.227^{* * *} \\
(.071)\end{array}$ \\
\hline Sample & World & World & World & World & World & \\
\hline Observations & 984 & 984 & 984 & 984 & 984 & \\
\hline $\mathrm{R}^{2}$ & .180 & .163 & .162 & .162 & .164 & \\
\hline
\end{tabular}

Notes: post represents the period from the year following the attack to the end of 2005, or, in the case of Egypt, the period from 1998 to 2000. post_1 represents the year immediately after the attack and post_2 the second year after the attack. 2002, 2003 and 2002-2005 are dummy variables describing the corresponding years. Given the short post period, no interactive term for the second year has been applied in the case of Morocco. isl is dummy denoting countries with a proportion of Islamic population of above $85 \%$. Robust standard errors (in parentheses) are adjusted for clustering on country. *, ${ }^{* *},{ }^{* * *}$ : significant at the $10 / 5 / 1 \%$ level.

In summary, individual events, such as the terror attack in Egypt in 1997, led to considerable declines in tourist flows in the regions affected over the short term (about a year), but the regions were able to recover relatively quickly. It was not 
until the combination of the 9/11 attacks and further terror attacks in subsequent years that tourist volumes were reduced in a sustained fashion in the cases reviewed in the study. The findings in Tables 2 and 3 have been visualised in Figure 2 as indices of the relative development of the tourist volume. The comparison consists of Islamic and non-Islamic countries (9/11) as well as countries affected directly by attacks (Egypt, Tunisia, Morocco and Indonesia) in relation to other Islamic countries.

\section{Fig. 2 Estimated Impact of Terrorism Attacks on Tourism}

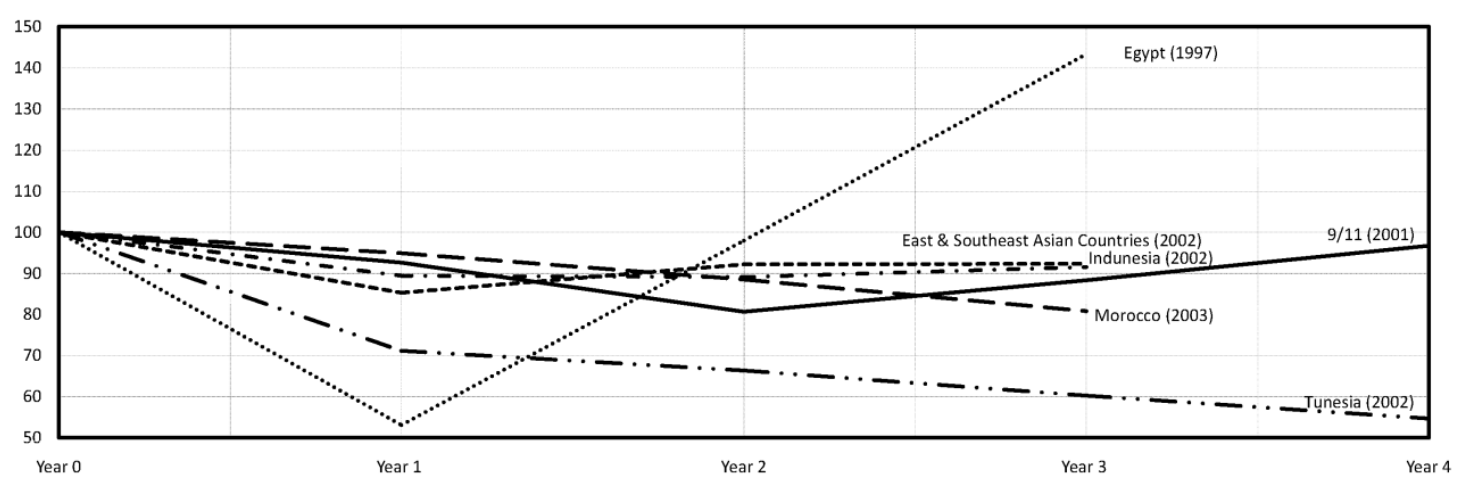

Notes: Figure shows indices of relative tourism development for years after intervention. For 9/11 index shows development of Islamic vs. non-Islamic countries, other indices refer to tourism in the respective countries while controlling for 9/11 effect (exception: Egypt, 1998-2000).

\section{Conclusion}

This study, the first to use a DD approach, examines changes in travel behaviour following 9/11 (2001) as well as the terror attacks in Egypt (1997), Tunisia (2002), Morocco (2003) and Indonesia (2003). As a result of the relative effects of 9/11 on tourist flows to Islamic and non-Islamic countries, changes in risk perception are not transferred exclusively by means of geographic but also ethnic-religious proximity. Islamic destination countries showed growth rates in tourist volume in 2002 and 2003 that were, on average, 7.4 and 12.9 percentage points, respectively, below those recorded by the non-Islamic control group. A recovery effect set in starting in 2004, so that at the end of 2005 tourist arrivals were only about 3.3 percent below those in non-Islamic countries relative to the starting position in 2001. This trend was accompanied by temporary substitution effects in favour of (Southern) European states. Moreover, in the course of the period under obser- 
vation a substitution effect was identified, with travellers opting for trips within closer proximity over long-distance travel, which was particularly highly significant in the year following 9/11.

The findings of the study of the terror attacks in Egypt, Tunisia and Morocco confirm, as already discussed by PIZAM \& FLEISCHER (2002) regarding the tourism industry of Israel, that the frequency of terror attacks, as well as their intensity, can be decisive for the time during which effects are noticeable. The tourist volume in Egypt after the 1997 attack more than recovered within only two years, while Morocco and Tunisia, which both suffered additional attacks, did not exhibit any indication of a significant recovery after two and three years ${ }^{16}$, respectively.

While attacks after 9/11 produced longer-lasting, stronger (negative) effects, a significant attenuation of the effects has been observed in the short term. These results provide initial proof of an adaptation effect, which was described by BLINDA \& HARMS (2006), but had not been studied empirically yet. While the short-term effects of the 1997 attack in Egypt were very strong, the effects in Tunisia and Morocco in the aftermath of the attacks in 2002 and 2003 were relatively minor. Apparently the attack in Egypt was a surprising and novel intervention, which was followed by an especially strong adjustment in risk perception. An adjustment of such extent is not observed with any of the subsequent attacks.

Regional spillover effects of terror attacks have been examined for the region Southeast Asia on the basis of the Bali terror attacks in 2002. ${ }^{17}$ The study has found in its (non-Islamic) neighbouring countries a significantly negative relative trend in tourism volume in 2003. The short-term effects were at least as marked as in Indonesia, which cannot be explained by regional spillover effects, but instead points to an additional impact from the infectious disease SARS, which had

${ }^{16}$ No evaluation was possible, as there were no data for 2006. Therefore negative effects even three years after the attacks cannot be ruled out for Morocco and Tunisia.

${ }^{17}$ Since there are no data for the Islamic countries in Africa or for non-Islamic countries in the Middle East, and since there are virtually no non-Islamic neighbouring countries, this line of inquiry has not been pursued for this region. 
devastated particularly the neighbouring countries in 2002. Over the long term, however, Indonesia, when compared to its neighbouring countries, shows stronger effects on tourist volume, which may indicate that terror attacks tend, in relative terms, to produce longer-term adjustments.

Finally, if tourists' subjective risk assessment following a terrorist attack depends-besides economic and geographic considerations-on social, ethnic and religious determinants, then similar mechanisms are likely to apply also to other economic agents, e.g., acting at financial markets. For instance, one might expect similar adjustments in the distribution of foreign direct investment. More research might lead to a more profound understanding on the transmission of a broader range of local economic shocks, which, with increasing integration, tend to affect more and more regional markets. 


\section{Literature}

AHLFELDT, G. M., \& MAENNIG, W. ([in press]). Arenas: Arena Architecture and the Impact on Location Disirability: The Case of „Olympic Arenas“ in Berlin-Prenzlauer Berg. Urban Studies.

AL-HAMARNEH, A. (2004). Islamischer Tourismus - Eine Chance für die dritte Welt? In G. MEYER (Ed.), Die arabische Welt im Spiegel der Kulturgeographie (Vol. 1, pp. 340-346). Mainz: Zentrum für Forschung zur Arabischen Welt [u.a.].

BALTAGI, B. H. (2001). Econometric Analysis of Panel Data. New York: John Wiley.

BERTRAND, M., DUFLO, E., \& MULLAINATHAN, S. (2004). How Much Should We Trust Difference-in-Difference Estimates? Quarterly Journal of Economics, 119(1), 249-275.

BLINDA, A., \& HARMS, F. (2006). Terror in der Türkei: Man gewöhnt sich an Anschläge. Retrieved 15.07.2008, from http://www.spiegel.de/reise/aktuell/0,1518,433902,00. html.

BONHAM, C., EDMONDS, C., \& MAK, J. (2006). The Impact of 9/11 and Other Terrible Events on Tourism in the United States and Hawaii. Journal of Travel Research, 45(1), 99-110.

BRADYAND, J., \& WIDDOWS, R. (1988). The Impact of World Events on Travel to Europe During the Summer of 1986. Journal of Travel Research, 26(3), 8-10.

COSHALL, J. T. (2003). The Threat of Terrorism as an Intervention on International Travel Flows. Journal of Travel Research, 42(1), 4-12.

CROUCH, G. I. (1992). Effects of Income and Price on International Tourism. Annals of Tourism Research, 19(4), 643-664.

CRP-INFOTEC (2008a). Chronologie der Terroranschläge 1993-2002. Retrieved 15.06.2008, from http://www.crp-infotec.de/08spezi/terror/anschlagchronik01.html.

CRP-INFOTEC (2008b). Chronologie der Terroranschläge ab 2003. Retrieved 15.06.2008, from http://www.crp-infotec.de/08spezi/terror/anschlagchronik02.html.

DI TELLA, R., \& SCHARGRODSKY, E. (2004). Do Police Reduce Crime? Estimates Using the Allocation of Police Forces after a Terror Attack. American Economic Review, 60(1), 115133.

DRAKOS, K., \& KUTAN, A. M. (2003). Regional Effects of Terrorism on Tourism in Three Mediterranean Countries. Journal of Conflict Resolution, 47(5), 621-641.

EDMONDS, C., \& MAK, J. (2006). Terrorism and Tourism in the Asia Pacific Region: Is Travel and Tourism in a New World after 9/11? East-West Center Working Papers, 2006(86).

EILAT, Y., \& EINAV, L. (2004). Determinants of International Tourism: A ThreeDimensional Panel Data Analysis. Applied Economics, 36(12), 1315-1327.

EISSA, N., \& LIEBMAN, J. B. (1996). Labor Supply Response to the Earned Income Tax Credit. Quarterly Journal of Economics, 111(2), 605-637. 
ENDERS, W., \& SANDLER, T. (1991). Causality between Transnational Terrorism and Tourism: The Case of Spain. Terrorism, 14(1), 49-58.

ENDERS, W., \& SANDLER, T. (2006). Distribution of Transnational Terrorism among Countries by Income Class and Geography after 9/11. International Studies Quarterly, 50(2), 367-393.

ENDERS, W., SANDLER, T., \& PARISE, G. F. (1992). An Econometric Analysis of the Impact of Terrorism on Tourism. Kyklos, 45(4), 531-554.

FLEISCHER, A., \& BUCCOLA, S. (2002). War, Terror, and the Tourism Market in Israel. Applied Economics, 34(11), 1335-1343.

GALSTER, G., TATIAN, P., \& PETTIT, K. (2004). Supportive Housing and Neighborhood Property: Value Externalities. Land Economics, 80(1), 33-54.

GARIN-MUNOZ, T., \& AMARAL, T. P. (2000). An Econometric Model for International Tourism Flows to Spain. Applied Economic Letters, 7(8), 525-529.

HOTCHKISS, J. L., MOORE, R. E., \& ZOBAY, S. M. (2003). Impact of the 1996 Summer Olympic Games on Employment and Wages in Georgia. Southern Economic Journal, 69(3), 691-704.

LEE, S., OH, C.-O., \& O'LEARY, J. T. (2005). Estimating the Impact of the September 11 Terrorist Attacks on the US Air Transport Demand Using Intervention Analysis. Tourism Analysis, 9(4), 355-361.

LEIBRITZ, W. (2004). Auswirkungen des Terrorismus auf die Volkswirtschaften und die Wirtschaftspolitik. Retrieved 04.06.2008, from http://www.das-parlament.de/2004/ 03-04/Beilage/007.html.

MANSFELD, Y. (1999). Cycles of War, Terror and Peace: Determinants and Management of Crisis and Recovery of the Israeli. Journal of Travel Research, 38(1), 30-36.

NONNENMACHER, G. (2005). Der Terror und der Islam. Schwere Terroranschläge seit dem 11. September 2001. Frankfurter Allgemeine Zeitung, 25.07.2005, p. 1.

PIZAM, A. (1999). A Comprehensive Approach to Classifying Acts of Crime and Violence at Tourism Destinations. Journal of Travel Research, 38(1), 5-12.

PIZAM, A., \& FLEISCHER, A. (2002). Severity Versus Frequency of Acts of Terrorism: Which Has a Larger Impact on Tourism Demand? Journal of Travel Research, 40(3), 337-339.

READY, K. J., \& DOBIE, K. (2003). Real and Perceived Terrorist Threats: Effects of September 11, 2001 Events on the U.S. Motorcoach-Based Tourism Industry. Journal of Travel and Tourism Marketing, 15(1), 59-76.

REDDING, S. J., \& STURM, D. M. (2008). The Costs of Remoteness: Evidence from German Division and Reunification. American Economic Review, 98(5), 1766-1797.

RUPP, N. G., HOLMES, G. M., \& DESIMONE, J. (2005). Airline Schedule Recovery after Airport Closures: Empirical Evidence since September 11. Southern Economic Journal, $71(4), 800-820$. 
SAUNDERS, J. A., SHARP, J. A., \& WITT, S. F. (1987). Practical Business Forecasting. London.

SEQUEIRA, T. N., \& NUNES, P. M. (2008). Does Country Risk Influence International Tourism?: A Dynamic Panel Data Analysis. The Economic Record, 84(6), 223-236.

STATISTISCHES BUNDESAMT DEUTSCHLAND (2007). Tourismus in Zahlen 2006. Retrieved 05.06.2008, from https://www-ec.destatis.de/csp/shop/sfg/bpm.html.cms.cBroker .cls?cmspath=struktur,vollanzeige.csp\&ID=1021197.

THE WORLD FACTBOOK OF THE CIA (2008). Retrieved 16.06.2008, from https:// www.cia.gov/library/publications/the-world-factbook/index.html.

TREMBLAY, P. (1989). Pooling International Tourism in Western Europe. Annals of Tourism Research, 16(4), 477-491.

VESTER, H.-G. (2001). Terrorismus und Tourismus. Retrieved 04.06.2008, from http:// www.bpb.de/publikationen/OBSKFJ,0,Terror_und_Tourismus.html.

WITT, S. F., \& WITT, C. A. (1995). Forecasting Tourism Demand: A Review of Empirical Research. International Journal of Forecasting, 11(3), 447-475.

WORLD TOURISM ORGANIZATION (2007). Tourism Highlight 2007 Edition. Retrieved 10.05.2008, from http://unwto.org/facts/eng/pdf/highlights/highlights_07_eng_hr .pdf.

WORLD TOURISM ORGANIZATION (2008). World Tourism Barometer, June 2008. Retrieved 17.07.2008, from http://unwto.org/facts/eng/pdf/barometer/UNWTO_ Barom08_2_en_Excerpt.pdf.

WORLD TOURISM ORGANIZATION (n.d.). Tourism and the World Economy. Retrieved 10.05.2008, from http://unwto.org/facts/eng/economy.htm. 


\section{Hamburg Contemporary Economic Discussions}

(Download: http://www.uni-hamburg.de/economicpolicy/discussions.html)

01/2005 FEDDERSEN, A. / MAENNIG, W.: Trends in Competitive Balance: Is there Evidence for Growing Imbalance in Professional Sport Leagues?, January 2005.

02/2005 SIEVERS, T.: Information-driven Clustering - An Alternative to the Knowledge Spillover Story, February 2005.

03/2005 SIEVERS, T.: A Vector-based Approach to Modeling Knowledge in Economics, February 2005.

04/2005 BUETTNER, N. / MAENNIG, W. / MENSSEN, M.: Zur Ableitung einfacher Multiplikatoren für die Planung von Infrastrukturkosten anhand der Aufwendungen für Sportstätten - eine Untersuchung anhand der Fußball-WM 2006, May 2005.

01/2006 FEDDERSEN, A.: Economic Consequences of the UEFA Champions League for National Championships - The Case of Germany, May 2006.

02/2006 FEDDERSEN, A.: Measuring Between-season Competitive Balance with Markov Chains, July 2006.

03/2006 FEDDERSEN, A. / VÖPEL, H.: Staatliche Hilfen für Profifußballclubs in finanziellen Notlagen? - Die Kommunen im Konflikt zwischen Imageeffekten und Moral-Hazard-Problemen, September 2006.

04/2006 MAENNIG, W. / SCHWARTHOFF, F.: Stadium Architecture and Regional Economic Development: International Experience and the Plans of Durban, October 2006. 


\section{Hamburg Contemporary Economic Discussions}

(Download: http://www.uni-hamburg.de/economicpolicy/discussions.html)

01

02

03

04

05

06

07

08

O9

10

11

12

13

AHLFELDT, G. / MAENNIG, W.: The Role of Architecture on Urban Revitalization: The Case of "Olympic Arenas" in Berlin-Prenzlauer Berg, 2007.

FEDDERSEN, A. / MAENNIG, W. / ZIMMERMANN, P.: How to Win the Olympic Games - The Empirics of Key Success Factors of Olympic Bids, 2007.

AHLFELDT, G. / MAENNIG, W.: The Impact of Sports Arenas on Land Values: Evidence from Berlin, 2007.

DU PLESSIS, S. I MAENNIG, W.: World Cup 2010: South African Economic Perspectives and Policy Challenges Informed by the Experience of Germany 2006, 2007.

HEYNE, M. / MAENNIG, W. / SUESSMUTH, B.: Mega-sporting Events as Experience Goods, 2007.

DUST, L. / MAENNIG, W.: Shrinking and Growing Metropolitan Areas - Asymmetric Real Estate Price Reactions? The Case of German Single-family Houses, 2007.

JASMAND, S. I MAENNIG, W.: Regional Income and Employment Effects of the 1972 Munich Olympic Summer Games, 2007.

HAGN, F. / MAENNIG W.: Labour Market Effects of the 2006 Soccer World Cup in Germany, 2007.

HAGN, F. I MAENNIG, W.: Employment Effects of the World Cup 1974 in Germany.

MAENNIG, W.: One Year Later: A Re-appraisal of the Economics of the 2006 Soccer World Cup, 2007.

AHLFELDT, G., MAENNIG, W.: Assessing External Effects of City Airports: Land Values in Berlin, 2007.

AHLFELDT, G.: If Alonso was Right: Accessibility as Determinant for Attractiveness of Urban Location, 2007.

AHLFELDT, G.: A New Central Station for a Unified City: Predicting Impact on Property Prices for Urban Railway Network Extension, 2007. 


\section{Hamburg Contemporary Economic Discussions}

(Download: http://www.uni-hamburg.de/economicpolicy/discussions.html)

FEDDERSEN, A. / MAENNIG, W.: Arenas vs. Multifunctional Stadia Which Do Spectators Prefer?, 2007.

AHLFELDT, G. / FEDDERSEN, A.: Geography of a Sports Metropolis, 2007.

FEDDERSEN, A. / GRÖTZINGER, A. / MAENNIG, W.: New Stadia and Regional Economic Development - Evidence from FIFA World Cup 2006 Stadia, 2008.

AHLFELDT, G. / MAENNIG, W.: Monumental Protection: Internal and External Price Effects, 2008.

MAENNIG, W. / PORSCHE, M.: The Feel-good Effect at Mega Sport Events - Recommendations for Public and Private Administration Informed by the Experience of the FIFA World Cup 2006, 2008.

AHLFELDT, G.: The Train has Left the Station: Real Estate Price Effects of Mainline Realignment in Berlin, 2008.

MAENNIG, W. / WELLBROCK, C.-M.: Sozio-ökonomische Schätzungen Olympischer Medaillengewinne: Analyse-, Prognose- und Benchmarkmöglichkeiten, 2008.

MAENNIG, W. / ALLERMS, S.: South Africa 2010: Economic Scope and Limits, 2008.

AHLFELDT, G. / FEDDERSEN, A.: Determinants of Spatial Weights in Spatial Wage Equations: A Sensitivity Analysis, 2008.

AHLFELDT, G. / WENDLAND, N.: Fifty Years of Urban Accessibility: The Impact of Urban Railway Network on the Land Gradient in Industrializing Berlin, 2008.

AHLFELDT, G. I FRANKE, B. / MAENNIG, W.: Terrorism and the Regional and Religious Risk Perception of Foreigners: The Case of German Tourists, 2009. 
